\title{
Modele i efekty współpracy „aktorów“ współtworzących krajobraz współczesnego miasta, na przykładzie działalności Katedry Projektowania Urbanistycznego i Krajobrazu Wiejskiego Wydziału Architektury Politechniki Warszawskiej
}

Models and effects of cooperation of "actors" contributing to townscape of contemporary city, on the example of activities of The Chair of Urban Design and Rural Landscape at The Faculty of Architecture, Warsaw University of Technology

\section{Streszczenie}

Artykuł przedstawia kształtowanie modeli współpracy uczelni (Katedry Projektowania Urbanistycznego i Krajobrazu Wiejskiego Wydziału Architektury Politechniki Warszawskiej), samorządu lokalnego i biznesu - „aktorów” współtworzących krajobraz współczesnych miast oraz efekty współpracy. Do najważniejszych rodzajów współpracy należą: organizacja konkursów studenckich architektoniczno-urbanistycznych, organizacja studenckich warsztatów projektowych architektoniczno-urbanistycznych, organizacja naukowych wycieczek studialnych krajowych i zagranicznych, udział pracowników Katedry w warsztatach projektowych krajowych i międzynarodowych, wykłady.

Słowa kluczowe: współpraca, uczelnia, samorząd, miasto, projektowanie architektoniczne i urbanistyczne

Abstract

The article presents shaping models of cooperation of the University (The Chair of Urban Design and Rural Landscape of the Faculty of Architecture, Warsaw University of Technology), local government and business - "actors" contributing to townscape of contemporary cities as well as the effects of cooperation. The most important types of cooperation include: organization of architectural and urban student competitions, organization of architectural and urban design workshops for students, organization of scientific study trips in Poland and abroad, participation of the staff of The Chair of Urban Design and Rural Landscape in national and international design workshops, lectures. 


\section{WSTĘP}

Przedmiotem współpracy uczelni - Katedry Projektowania Urbanistycznego i Krajobrazu Wiejskiego Wydziału Architektury Politechniki Warszawskiej, samorządu lokalnego i biznesu - są problemy rozwoju miast, zwłaszcza dużych aglomeracji (takich jak Warszawa, Berlin, Paryż, Hamburg, Frankfurt) w zakresie ich zagospodarowania przestrzennego.

W przypadku wykonywania w ramach współpracy projektów zagospodarowania przestrzennego wybranych obszarów analizom i badaniom poddane zostają obszary, pełniące istotną rolę $\mathrm{w}$ strukturze przestrzennej miasta, kształtowaniu tożsamości dzielnicy bądź całego miasta. Jednocześnie są to często miejsca, które wymagają podjęcia konkretnych działań z powodu występujących na nich konfliktów przestrzennych, zaniedbań oraz powstania nowych współczesnych potrzeb użytkowania.

Głównymi efektami współpracy są projekty, publikacje w czasopismach, publikacje w formie druków zwartych, publikacje internetowe, wystawy, publiczne dyskusje prowadzące do formułowania wniosków i wytycznych dla realizacji.

Do najważniejszych osiągnięć Katedry Projektowania Urbanistycznego i Krajobrazu Wiejskiego Wydziału Architektury Politechniki Warszawskiej zaliczyć należy następujące rodzaje współpracy:

1) współpraca z Instytutem Planowania Miast i Regionów Technicznego Uniwersytetu w Berlinie (Institut für Stadt- und Regionalplanung, Technische Universität Berlin) (jednym z głównych efektów jest opracowanie przedmiotu pt. Seminarium fakultatywne WARSZAWA - BERLIN), 2002-2017.

2) współpraca ze Szkołą Główną Handlową i Urzędem Dzielnicy Mokotów (dwa równoległe konkursy dla studentów Wydziału Architektury Politechniki Warszawskiej: a) koncepcja miejscowego planu zagospodarowania przestrzennego rejonu historycznego kampusu SGH wraz z otoczeniem, b) koncepcja zabudowy i zagospodarowania najbliższego otoczenia budynku głównego szkoły, tzw. Brama Mokotowa; główne efekty to: wystawa projektów, publiczna dyskusja, publikacja pt. Historyczny Kampus Szkoły Głównej Handlowej w Warszawie w studenckich konkursach urbanistycznych), 2014 (il. 1-3).

3) współpraca z Fundacją Patriotyczną „Serenissima” (konkurs dla studentów II roku studiów inżynierskich Wydziału Architektury Politechniki Warszawskiej na projekt pomnika Bitwy Warszawskiej 1920 roku), 2015.

4) współpraca z Zarządem Transportu Miejskiego w Warszawie (konkurs dla studentów I roku studiów magisterskich na koncepcję zagospodarowania rejonu Dworca Południowego w Dzielnicy Mokotów m. st. Warszawy; główne efekty to: wystawa projektów, publiczna dyskusja, publikacje w czasopismach), 2015-2016 (il. 4-5).

5) współpraca z Uniwersytetem Warszawskim (konkurs dla studentów I roku studiów magisterskich pt. Ulica Dobra jako oś integracji dzielnicy uniwersyteckiej, jednym z głównych efektów była wystawa projektów), 2016-2017 (il. 6-7). 


\section{MODEL WSPÓŁPRACY TYPU UCZELNIA - UCZELNIA - SAMORZĄD - BIZNES NA PRZYKŁADZIE WSPÓŁPRACY KATEDRY PROJEKTOWANIA URBANISTYCZNEGO I KRAJOBRAZU WIEJSKIEGO WYDZIAtU ARCHITEKTURY POLITECHNIKI WARSZAWSKIEJ Z INSTYTUTEM PLANOWANIA MIAST I REGIONÓW TECHNICZNEGO UNIWERSYTETU W BERLINIE (INSTITUT FÜR STADT- UND REGIONALPLANUNG, TECHNISCHE UNIVERSITÄT BERLIN)}

\subsection{WPROWADZENIE}

Rozpoczęta w 1992 roku przez profesora doktora Klausa Künkla współpraca między Wydziałem Architektury Politechniki Warszawskiej a Instytutem Planowania Miast i Regionów Technicznego Uniwersytetu w Berlinie (Institut für Stadt- und Regionalplanung, Technische Universität Berlin) zaowocowała organizacją wspólnych Polsko-Niemieckich Warsztatów Projektowych dla studentów z obu uczelni. Warsztaty organizowane są co roku (od 2002 r.), a ich głównym celem jest opracowanie spójnej wizji zagospodarowania przestrzennego różnych fragmentów Warszawy i Berlina, które wymagają interwencji urbanistycznej.

Zebrane przez wiele lat doświadczenia, pozwoliły na ostateczne opracowanie w latach 2014 i 2015 autorskiego programu nauczania - przedmiotu pt. Seminarium fakultatywne WARSZAWA - BERLIN. Seminarium odbywa się w formie wykładów, dyskusji i warsztatów projektowych. W programie znajdują się także pozycje powiązane z tematem projektu, takie jak wycieczki studialne na temat najnowszych problemów rozwoju Warszawy i Berlina, wystawy i wizyty w instytucjach i innych miejscach, pogłębiające wiedzę na zadany temat. Seminarium prowadzone jest w języku angielskim.

W ramach seminarium powstają nowatorskie rozwiązania projektowe, zachowujące jednocześnie najbardziej wartościowe cechy środowiska naturalnego i zbudowanego danego miejsca. Jednocześnie Seminarium fakultatywne WARSZAWA - BERLIN jest dobrą okazją dla studentów z różnych krajów do wymiany wiedzy i doświadczeń w zakresie planowania rozwoju miast, rozwoju nowych umiejętności naukowo-badawczych i projektowych, nawiązywania międzynarodowych kontaktów oraz rozwijania umiejętności prezentacji rozwiązań projektowych i prowadzenia dyskusji w grupie międzynarodowej.

Dodać należy, że na opracowanie ostatecznej formy seminarium miało wpływ wiele doświadczeń związanych zarówno z prowadzonym przedmiotem, jak i z wieloma innymi aktywnościami podejmowanymi przez pracowników, takimi jak liczne prace naukowe i badawcze, udział w międzynarodowych wymianach naukowych, konferencjach i warsztatach, opracowanie i prowadzenie naukowych wycieczek dla studentów z wielu uniwersytetów zagranicznych, stypendia i wykłady zagraniczne.

Rezultatem prowadzenia przedmiotu Seminarium fakultatywne WARSZAWA - BERLIN są zarówno publikacje wyników seminarium (w postaci druków zwartych oraz opracowań 
zawartych na stronach internetowych Instytutu Planowania Miast i Regionów Uniwersytetu Technicznego w Berlinie), jak i inne liczne publikacje pracowników związane z podejmowaną tematyką seminarium. Kilkakrotnie prezentacja wyników seminarium odbyła się w formie wystawy w Berlinie wraz z dyskusją z udziałem przedstawicieli Uniwersytetu Technicznego w Berlinie i innych instytucji (miejsca organizacji wystaw i dyskusji: Rathaus Kreuzberg i inne). Rezultatem prowadzenia seminarium jest także rozwój u studentów wyobraźni przestrzennej, pamięci wizualnej, umiejętności obserwacji i badania struktury funkcjonalno-przestrzennej współczesnych miast (w tym najnowszych założeń architektonicznych i urbanistycznych) oraz rozwój umiejętności kreacji przestrzeni.

\subsection{CELE PRZEDMIOTU „SEMINARIUM FAKULTATYWNE WARSZAWA - BERLIN”}

Miasta są ośrodkami rozwoju kultury i nauki, jak również głównymi czynnikami i miejscami rozwoju gospodarczego i postępu społecznego. Jako centra cywilizacji, miejsca koncentracji istotnych zasobów i sieci wpływów - prawidłowo zaplanowane i zarządzane - dają szansę rozwoju człowiekowi i chronią zasoby naturalne dzięki koncentracji ludzi przy jednoczesnym ograniczeniu ich wpływu na środowisko naturalne.

Niestety, w XXI wielu na obszarach miejskich nasiliły się procesy destrukcyjne, takie jak nadmierne rozrastanie się terytorialne miast oraz postępująca degradacja środowiska zurbanizowanego. Reakcją na te przemiany jest znaczny wzrost zainteresowania występującymi problemami rozwoju miast i podejmowanie prób ich rozwiązywania. Wśród najważniejszych działań wymienić należy: rewitalizację i rozwój wewnętrznych obszarów miast (w tym obszarów zaniedbanych, obszarów tracących znaczenie oraz terenów niezagospodarowanych), strategię podniesienia jakości środowiska zbudowanego, strategię kreacji wysokiej jakości przestrzeni publicznych, strategię respektowania odrębnej kulturowej tożsamości każdego miasta, czyli respektowania jego „genius loci”, strategię modernizacji sieci infrastrukturalnych i poprawy efektywności wydatkowania energii, strategię promocji społecznie akceptowanego miejskiego transportu.

Stąd podstawowym celem "Seminarium fakultatywnego WARSZAWA-BERLIN" jest przybliżenie jego uczestnikom problematyki dużych miast na przykładzie Warszawy i Berlina, przekazanie wiedzy na temat problemów ich rozwoju - w ujęciu historycznym i współcześnie, a następnie zastosowanie zdobytej wiedzy w rozwiązywaniu konkretnego problemu, będącego tematem zadania projektowego (za pomocą narzędzi takich jak projektowanie urbanistyczne, planowanie miejscowe czy kompozycja urbanistyczna).

Jednocześnie celem przedmiotu jest wymiana doświadczeń naukowych i projektowych między studentami z różnych ośrodków akademickich dzięki organizacji pracy w międzynarodowym zespole. 


\subsection{TEMATYKA I OGÓLNY OPIS PRZEDMIOTU „SEMINARIUM FAKULTATYWNE WARSZAWA - BERLIN"}

Tematyka seminariów dotyczy ważnych obszarów Warszawy i Berlina, które wymagają interwencji urbanistycznej. Są to obszary, które w ostatnich latach podlegały znacznym przekształceniom, lub takie, które wymagają rewitalizacji i rewaloryzacji. Należą do nich obszary poprzemysłowe, kolejowe, nabrzeżne (brzegi wód otwartych), nieużytki miejskie, centra dzielnic, przestrzenie publiczne, tereny otwarte (w tym cenne obszary dziedzictwa naturalnego i kulturowego), zdegradowane obszary mieszkaniowe.

Analizy ogólne dotyczą kształtowania formy przestrzennej miasta, sposobu użytkowania terenów, systemów transportu, systemów terenów otwartych (w tym systemu przestrzeni publicznych). Niezwykle istotna jest identyfikacja najważniejszych cech wpływających na tożsamość danego miasta. Zakres analiz ogólnych obejmuje obszar miasta w jego granicach administracyjnych z uwzględnieniem problemów rozwoju obszaru metropolitalnego.

Analizy szczegółowe dotyczą problemów rozwoju przestrzennego wybranego obszaru w danym mieście. Obszar ten pełni istotną rolę $w$ strukturze przestrzennej miasta, kształtowaniu tożsamości dzielnicy bądź całego miasta. Jednocześnie jest to miejsce, które wymaga podjęcia konkretnych działań z powodu występujących na nim konfliktów przestrzennych, zaniedbań oraz powstania nowych współczesnych potrzeb użytkowania. Stąd kolejnym etapem pracy jest projekt zagospodarowania przestrzennego tego obszaru. Zakres opracowania zależy od wielkości obszaru i jego charakteru. Ogólnie wymagane są: 1) analizy zagospodarowania przestrzennego miasta lub dzielnicy w skali wyjaśniającej istniejące problemy rozwoju przestrzennego, 2) inwentaryzacja stanu istniejącego obszaru w skali 1:2000 lub 1:1000, 3) projekt zagospodarowania przestrzennego obszaru w skali 1:2000 lub 1:1000 oraz detale rozwiązań w skali 1:1000 lub 1:500. Kolejnym etapem realizacji celów przedmiotu może być także opracowanie naukowe, wskazujące uwarunkowania i kierunki zagospodarowania przestrzennego badanego obszaru. Seminarium (dla studentów II sem. studiów magisterskich) podzielone jest na dwa etapy: I - zajęcia w formie cotygodniowych spotkań, II - międzynarodowe warsztaty projektowe w języku angielskim, w dwóch zblokowanych okresach tygodniowych, z których jeden tydzień odbywa się w Warszawie, a drugi w Berlinie.

Przykładowo na seminarium w roku akademickim 2014/2015 opracowano temat: Przyczółek Grochowski Housing Estate in Warsaw - Back to the City. Skupiono się na problemie zdegradowanego osiedla mieszkaniowego z lat 60. XX wieku, które stanowi istotne ogniwo w rozwoju myśli urbanistycznej tego okresu. Zadaniem studentów było opracowanie koncepcji przekształceń obszaru według wybranego/zaproponowanego scenariusza działań w celu przywrócenia osiedlu należnej mu roli w mieście. 
W latach 2002-2015 zorganizowano następujące seminaria:

1) „Conception of development of The Stralau Peninsula in Berlin”, 2002, przygotowanie i prezentacja wyników warsztatów w formie wystawy w Berlinie w Wasserstadt GmbH (11 plansz 100x70), dyskusja z udziałem przedstawicieli Senatu Berlina, Uniwersytetu Technicznego w Berlinie i innych instytucji, Berlin 2002.

2) "Towards a Definition of the Southern Urban Fringe in Warsaw", 2003.

3) „The city Centre of Pankow, Berlin-Urban Design in a Built-Up Area”, 2004, przygotowanie i prezentacja wyników warsztatów w formie wystawy w Berlinie w Rathaus Pankow, dyskusja z udziałem przedstawicieli Uniwersytetu Technicznego w Berlinie i innych instytucji, Berlin 2004.

4) „IMIELIN LAKE in Warsaw - urbanized suburb or city district?”, 2005.

5) „Urban Lock - nördliche Lohmühleninsel”, 2006, przygotowanie i prezentacja wyników warsztatów w formie wystawy w Berlinie w Rathaus Kreuzberg, dyskusja z udziałem przedstawicieli Uniwersytetu Technicznego w Berlinie i innych instytucji, Berlin 2007.

6) „Mokotów meeting point of Culture and Nature in Warsaw”, 2007 (il. 8).

7) „Ships \& Shifts - Rethinking Neukölln Harbour”, 2008.

8) „Public Space of The Main Historical Axis of Natolin District in Warsaw (Przy Bażantarni Street - Pheasant street)", 2009.

9) „Fly Over Bierpinsel: Post - Oil - Megastructure - Designing”, 2010.

10) „Public Space of Gandhi street in Ursynów district, Warsaw”, 2011.

11) „From Mono to Multi Qualifying Gropiusstadt in Berlin”, 2012.

12) „Przyczółek Grochowski - Housing Estate in Warsaw”, 2013.

13) „Fundamentals - The revision of Hobrechtplan 1914-2014”, 2014.

14) „Warsaw Breweries Site Development Strategy - Back to the City Center”, 2015.

\subsection{PROWADZAZCY „SEMINARIUM FAKULTATYWNE WARSZAWA - BERLIN”}

Od 2002 roku warsztaty projektowe (obecnie "Seminarium fakultatywne WARSZAWA - BERLIN") prowadzili pracownicy Institut für Stadt- und Regionalplanung, Technische Universität Berlin: Prof. Dipl-Ing. Elke Pahl-Weber, Dr-Ing. Ursula Flecken, Dipl-Ing. Nikolai Roskamm, Dipl-Ing. Roland Klein-Knott, Dipl-Ing. Florian Hutterer, Dipl-Ing. Christoph Hoja, Dipl.-Ing. Toni Karge, oraz pracownicy Katedry Projektowania Urbanistycznego i Krajobrazu Wiejskiego Wydziału Architektury Politechniki Warszawskiej: prof. dr hab. inż. arch. Sławomir Gzell, dr hab. inż. arch. Katarzyna Pluta, prof. PW (opracowanie 5 tematów seminariów), mgr inż. arch. Katarzyna Kierczyńska-Królikowska (opracowanie 3 tematów seminariów) ${ }^{1}$. 


\subsection{PODSUMOWANIE}

Seminarium fakultatywne, cieszące się dużym zainteresowaniem studentów polskich i niemieckich, przyczynia się do interesującej wymiany poglądów między studentami i kadrą akademicką obu wyższych uczelni oraz samorządami lokalnymi na tematy współczesnego rozwoju miast stołecznych - ośrodków metropolitalnych, aspirujących do uzyskania znaczenia w skali globalnej. Dotychczasowe seminaria ujawniły zbieżności i różnice $w$ procesach inwestycyjnych, planowania, projektowania tych miast i ich przekształceń, rewitalizacji i nowych kierunków rozwoju. Dotyczyło to zarówno rozwijania tożsamości kulturowych miast, jak i poszukiwania współczesnych oraz atrakcyjnych koncepcji przekształceń wybranych fragmentów miast, w tym nowych pomysłów transportu miejskiego (zwłaszcza szynowego, rowerowego), ale także rozwoju publicznych przestrzeni pieszych, decydujących o życiu miasta i współuczestniczeniu w nim jego mieszkańców.

Wprowadzenie autorskiego i wyróżniającego się programu nauczania - przedmiotu pt. "Seminarium fakultatywne WARSZAWA - BERLIN" i jego ostateczne opracowanie w latach 2014-2015 spowodowało istotną poprawę wyników kształcenia na Wydziale Architektury Politechniki Warszawskiej, w tym możliwość porównania polskich metod projektowania i nauczania z rozwiązywaniem podobnych zagadnień w środowisku europejskim.

Efektami współpracy z Instytutem Planowania Miast i Regionów Technicznego Uniwersytetu w Berlinie są liczne publikacje wyników seminariów, na przykład:

1) Pluta K., Podstata G., Roskamm N., Seelig S., Urban Lock - nördliche Lohmühleninsel (Städtebaulicher Workshop zur Lohmühleninsel), Urban Design Workshop 2006²,

2) Gzell S., Pluta K., Roskamm N., Mokotów meeting point of Culture and Nature in Warsaw, Urban Design Workshop $2007^{3}$.

\section{MODEL WSPÓŁPRACY TYPU UCZELNIA - FUNDACJA NA PRZYKŁADZIE WSPÓŁPRACY KATEDRY PROJEKTOWANIA URBANISTYCZNEGO I KRAJOBRAZU WIEJSKIEGO WYDZIAŁU ARCHITEKTURY POLITECHNIKI WARSZAWSKIEJ Z FUNDACJĄ PATRIOTYCZNĄ „SERENISSIMA"}

\subsection{WPROWADZENIE}

W 2015 roku Katedra Projektowania Urbanistycznego i Krajobrazu Wiejskiego Wydziału Architektury Politechniki Warszawskiej zorganizowała we współpracy z Fundacją Patriotyczną „Serenissima” konkurs na projekt pomnika Bitwy Warszawskiej 1920 roku. W konkursie wzięło udział 160 studentów z Wydziału Architektury Politechniki Warszawskiej. Projekt był wykonany w ramach obowiązkowych zajęć z przedmiotu pt. „Elementy Kompozycji Urbanistycznej", prowadzonego przez Katedrę Projektowania Urbanistycznego i Krajobrazu Wiejskiego Wydziału Architektury Politechniki Warszawskiej. 


\subsection{POMNIK BITWY WARSZAWSKIEJ 1920}

Znaczenie Bitwy Warszawskiej 1920 dla narodu polskiego jest oczywiste i udowodnione. Wystarczy przypomnieć, że historycy zaliczają ją do kilkunastu najważniejszych wydarzeń w historii Europy, może nawet świata, które zmieniły bieg historii. Wydarzeń takich, będących dziełem Polaków, nie ma zbyt wiele, więc tym bardziej należy pamięć o zwycięskiej Bitwie Warszawskiej w odpowiedni sposób utrwalać i eksponować.

Bitwa odbywała się na przedpolach Warszawy, za jej wschodnimi rogatkami, i znajdujące się tam miejsca związane z przebiegiem bitwy są już dawno zaznaczone w przestrzeni. Odbywają się przy nich rozmaite uroczystości rocznicowe i inne uroczystości o zabarwieniu patriotycznym, żadne z nich nie ma jednak charakteru, powiedzmy, „miejsca centralnego”. Być może jest to sytuacja poprawna, bitwa nie była wydarzeniem punktowym, jej pole (raczej pola) to wielka przestrzeń i każdy jej fragment ma swoją lokalną kulminację. Z drugiej strony nie może się obejść bez pomnika głównego, chociażby monumentu w rodzaju krakowskiego Pomnika Grunwaldzkiego. Rozpatrywano rozmaite lokalizacje dla jego warszawskiego odpowiednika. Po pierwsze, analizowano tereny w dolinie Wisły, również z tego powodu, że bitwa warszawska nosi nazwę Cudu nad Wisłą. Jednakże żadne z przywoływanych miejsc nie wydało się odpowiednie. Po drugie, analizowano miejsca wzdłuż leżącej na Ochocie ulicy Bitwy Warszawskiej, ale i te lokalizacje nie są dostatecznie dobrze uzasadnione. Szukano także miejsc specjalnych, np. w pobliżu lokalizacji poprzednio wskazywanej dla Muzeum Historii Polski. Wszystkie wspomniane i analizowane lokalizacje mają jedną wspólną wadę: są peryferyjnie położone w stosunku do głównych przestrzeni publicznych Warszawy, gdzie, za przykładem innych miast, pomnik rangi, o jakiej mówimy, powinien się znaleźć.

Z dotychczasowych rozważań wynika, że pomnik Bitwy Warszawskiej powinien znaleźć się w śródmieściu Warszawy. Tu sytuacja się komplikuje, ponieważ obszar ten jest wypełniony wszelkiego rodzaju pomnikami. Tylko wzdłuż Traktu Królewskiego jest ich kilkanaście (Kolumna Zygmunta III Wazy, pomnik Adama Mickiewicza, pomnik księcia Józefa Poniatowskiego, pomnik Bolesława Prusa, pomnik prymasa Stefana Wyszyńskiego, pomnik Mikołaja Kopernika, pomnik Charles'a de Gaulle'a, pomnik Wincentego Witosa, pomnik Ronalda Reagana, pomnik Stefana Roweckiego „Grota”, pomnik Romana Dmowskiego, nie licząc upamiętnień religijnych i pomników w bezpośrednim sąsiedztwie: pomnik Armii Krajowej i Polskiego Państwa Podziemnego, pomnik Fryderyka Chopina, pomnik Ignacego Jana Paderewskiego, pomnik Henryka Sienkiewicza). Ale to oznacza, że należy szukać w Warszawie nowych „osi pomnikowych” lub rozbudowywać istniejące, ale jeszcze nie wypełnione.

Do takich „osi pomnikowych” należy Oś Saska. Idąc od Krakowskiego Przedmieścia, mamy pomnik Józefa Piłsudskiego, krzyż upamiętniający mszę świętą celebrowaną przez papieża Jana Pawła II 2 czerwca 1979 roku, potem Grób Nieznanego Żołnierza i za ulicą 
Marszałkowską pomnik Tadeusza Kościuszki. Drugą możliwością jest wzniesienie pomnika pomiędzy jednokierunkowymi jezdniami ulicy Marszałkowskiej.

Trzecia możliwość to wykorzystanie projektu przesunięcia wschodniej jezdni ulicy Marszałkowskiej w kierunku zachodnim, z usytuowaniem torowiska tramwajowego między nowymi jezdniami, i budowa pomnika na uzyskanym (odzyskanym dla miasta) terenie ${ }^{4}$.

Wydaje się, że można by połączyć (wzajemnie wykorzystać) prace nad rewaloryzacją Ogrodu, a przynajmniej jego zachodniej części, z budową pomnika Bitwy Warszawskiej w tym rejonie Ogrodu, ale nie jest to konieczne. Oczywiście niezbędne będą zmiany w projekcie rewaloryzacji Ogrodu, ale w zamian uzyska on niezwykle ważny element. Najważniejszą zmianą będzie przygotowanie placu (płaszczyzny) przeznaczonego na wszelkiego rodzaju zebrania większej ilości osób wokół pomnika.

Pomnik ulokowany w proponowanym miejscu będzie wyeksponowany ze wszystkich stron i będzie widoczny w krajobrazie miasta. Widok wzdłuż ulicy Marszałkowskiej od południa oraz od strony placu Bankowego nie będzie kończył się pustką wypełnioną drzewami Ogrodu, o niezbyt dostrzegalnej kompozycji. Pomnik stanie się dominantą, znakiem szczególnym, ogniskującym spojrzenia, co jest naturalną rolą takich budowli. Zielona ściana drzew z tyłu pomnika, czyli Ogród Saski, będzie dla pomnika odpowiednim tłem. Wnętrze urbanistyczne, jakie tam już się wytworzyło, uzyska znakomitą kulminację, co z punktu widzenia kształtowania miejskiej przestrzeni publicznej ma ogromne znaczenie. Jeśli chodzi o gabaryty, to pomnik, zajmując dość dużą przestrzeń z powodu płaszczyzny niezbędnej do organizacji wokół niego uroczystych spotkań z udziałem oddziałów Wojska Polskiego i licznych delegacji, nie musi wznosić się zbyt wysoko. Powinien raczej osiągnąć skalę, którą można nazwać ludzką, ułatwiającą kontakt z widzem, i powinien być zrozumiały dla każdej z oglądających go osób.

Przesunięcie wschodniej jezdni wraz z torowiskiem tramwajowym na zachód pozwoliłoby na powiększenie Ogrodu Saskiego o obecną wyspę pomiędzy jezdniami. Lokalizacja ta wzmocniłaby Oś Saską i zapewniłaby wyeksponowanie pomnika w jednym z najbardziej ruchliwych miejsc Warszawy. Pomnik widoczny byłby zarówno ze skrzyżowania ul. Marszałkowskiej z ul. Świętokrzyską, jak i z placu Bankowego.

Wszystkie te uwagi nie przesądzają kształtu pomnika, co powinno być wynikiem konkursu. Próbą takiego rozwiązania jest studencki konkurs, zorganizowany we współpracy z Fundacją Patriotyczną „Serenissima”, a w zasadzie z jej inicjatywy, w którym wzięło udział 160 studentów (studenci trzeciego semestru studiów I stopnia - cały drugi rok z Wydziału Architektury Politechniki Warszawskiej). Projekt był wykonany w ramach obowiązkowych zajęć z przedmiotu pt. „Elementy Kompozycji Urbanistycznej”, prowadzonego przez Katedrę Projektowania Urbanistycznego i Krajobrazu Wiejskiego Wydziału Architektury Politechniki Warszawskiej. Studenci mieli dwa tygodnie na wykonanie pracy ${ }^{5}$ (il. 9-11). 


\subsection{WNIOSKI}

Zorganizowanie konkursu to wyróżniające się osiągnięcie organizacyjne, które wpłynęło na poprawę współpracy z otoczeniem społeczno-gospodarczym w zakresie prowadzenia badań naukowych, dotyczących kształtowania struktury przestrzennej współczesnych miast, oraz w zakresie podkreślania i utrwalania pamięci o ważnych wydarzeniach w historii Polski i Europy.

\section{PODSUMOWANIE}

Katedra Projektowania Urbanistycznego i Krajobrazu Wiejskiego Wydziału Architektury Politechniki Warszawskiej często inicjuje różne formy współpracy lub odpowiada pozytywnie na propozycje współpracy zgłaszane przez instytucje, organizacje, stowarzyszenia i wszelkie formalne i nieformalne grupy mieszkańców miast ${ }^{6}$.

Można określić kilka głównych modeli współpracy: uczelnia - uczelnia - samorząd lokalny - biznes, uczelnia - samorząd lokalny, uczelnia - fundacja, uczelnia - uczelnia - biznes.

Podkreślić należy, że dobra współpraca możliwa jest przy zaangażowaniu osób, którym zależy na współpracy i na jej wynikach. Należą do nich zarówno rektorzy i profesorowie uczelni wyższych, jak i burmistrzowie poszczególnych dzielnic Warszawy i innych miast oraz naczelnicy wydziałów architektury i budownictwa urzędów dzielnic. Wszystkim osobom zaangażowanym we współpracę z Katedrą bardzo dziękujemy.

W ramach współpracy powstają często znakomite projekty studenckie, ukazujące w trzecim wymiarze idee rozwoju różnych obszarów miast. Projekty te stanowią podstawę do twórczych publicznych dyskusji (wraz z udziałem lokalnych społeczności) oraz do formułowania wniosków i wytycznych do ich realizacji. 


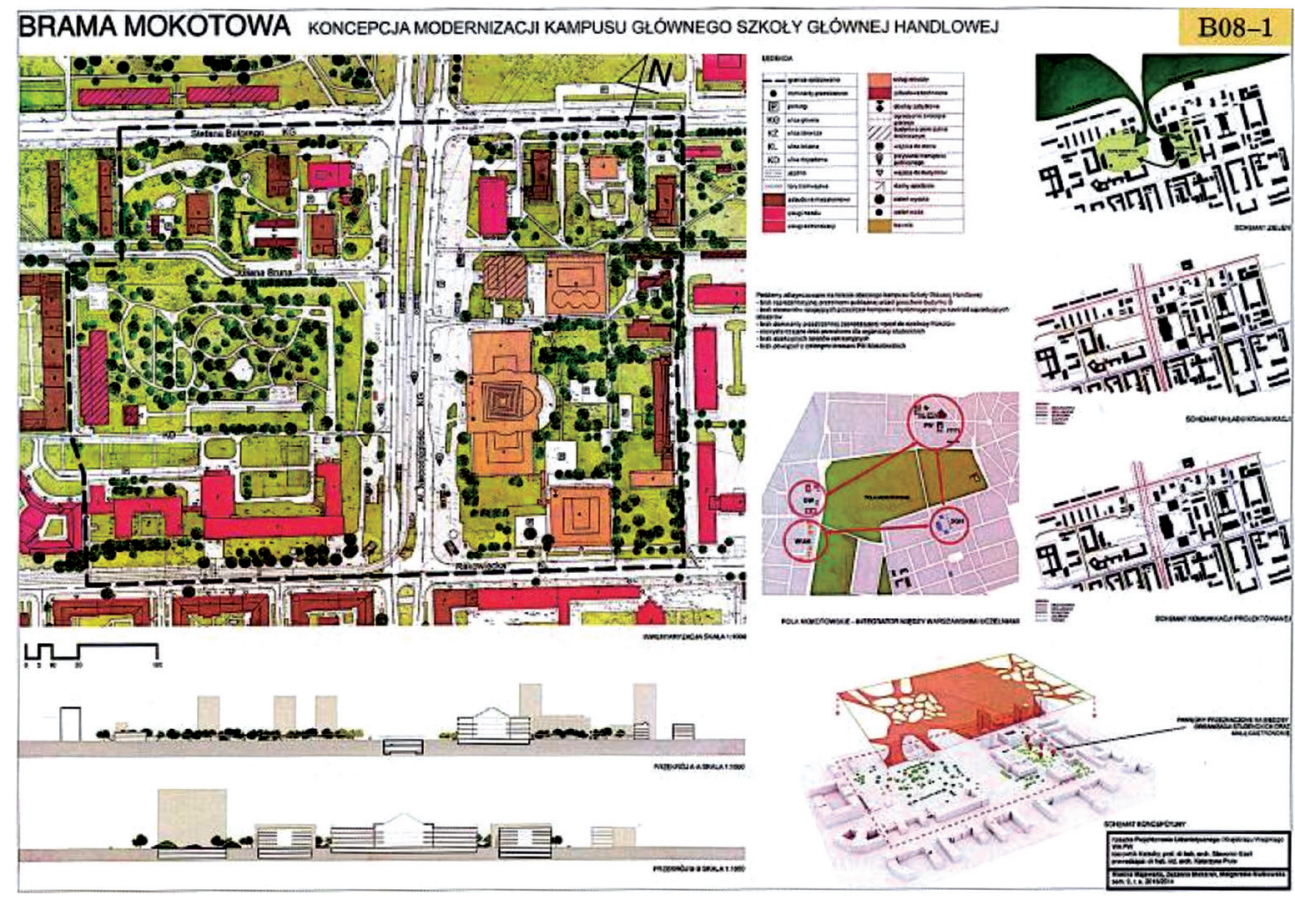

II. 1. Koncepcja zabudowy i zagospodarowania najbliższego otoczenia budynku głównego SGH

- „Brama Mokotowa”, Warszawa, 2014, autorki: Monika Majewska, Zuzanna Makaruk, Małgorzata Mutkowska, prowadzący projekt: dr hab. inż. arch. Katarzyna Pluta (źródło: Materiały archiwalne Katedry Projektowania Urbanistycznego i Krajobrazu Wiejskiego Wydziału Architektury Politechniki Warszawskiej)

III. 1. Concept of development of the closest surroundings of the main building of SGH - “Mokotów Gate”, Warsaw 2014 


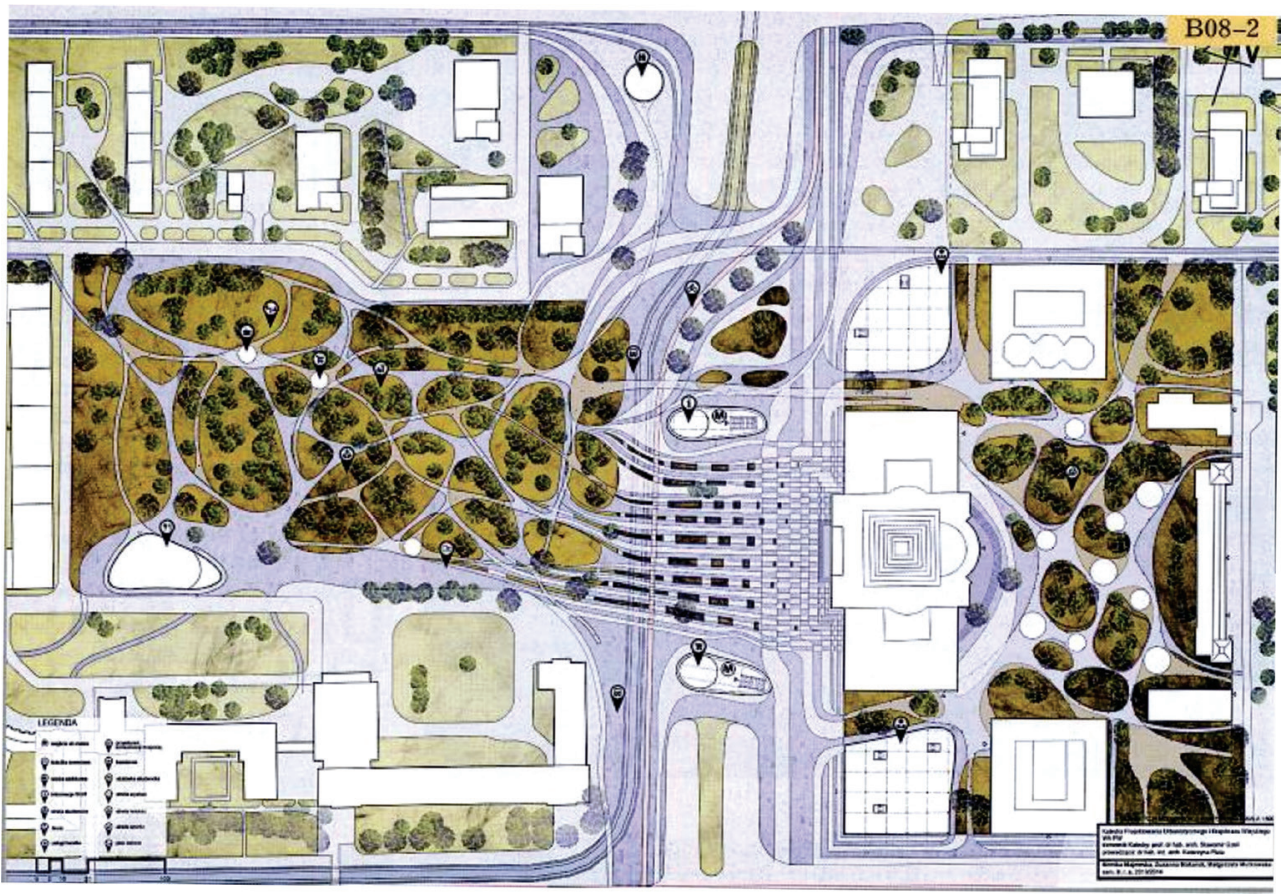

II. 2. Koncepcja zabudowy i zagospodarowania najbliższego otoczenia budynku głównego SGH - „Brama Mokotowa”, Warszawa, 2014, autorki: Monika Majewska, Zuzanna Makaruk, Małgorzata Mutkowska, prowadzący projekt: dr hab. inż. arch. Katarzyna Pluta (źródło: Materiały archiwalne Katedry Projektowania Urbanistycznego i Krajobrazu Wiejskiego Wydziału Architektury Politechniki Warszawskiej)

III. 2. Concept of development of the closest surroundings of the main building of SGH

- "Mokotów Gate", Warsaw 2014 


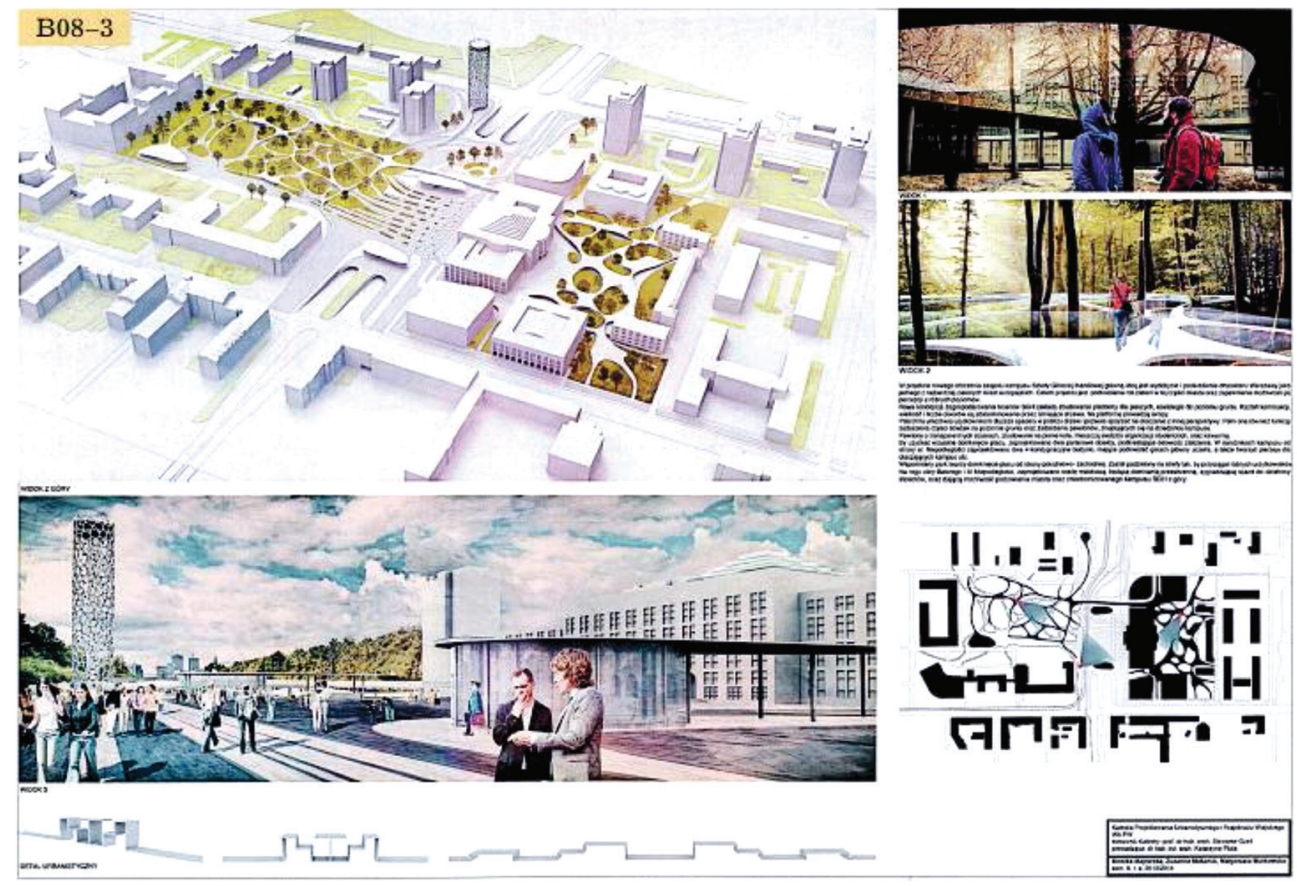

II. 3. Koncepcja zabudowy i zagospodarowania najbliższego otoczenia budynku głównego SGH - „Brama Mokotowa”, Warszawa, 2014, autorki: Monika Majewska, Zuzanna Makaruk, Małgorzata Mutkowska, prowadzący projekt: dr hab. inż. arch. Katarzyna Pluta (źródło: Materiały archiwalne Katedry Projektowania Urbanistycznego i Krajobrazu Wiejskiego Wydziału Architektury Politechniki Warszawskiej)

III. 3. Concept of development of the closest surroundings of the main building of SGH - "Mokotów Gate”, Warsaw 2014 


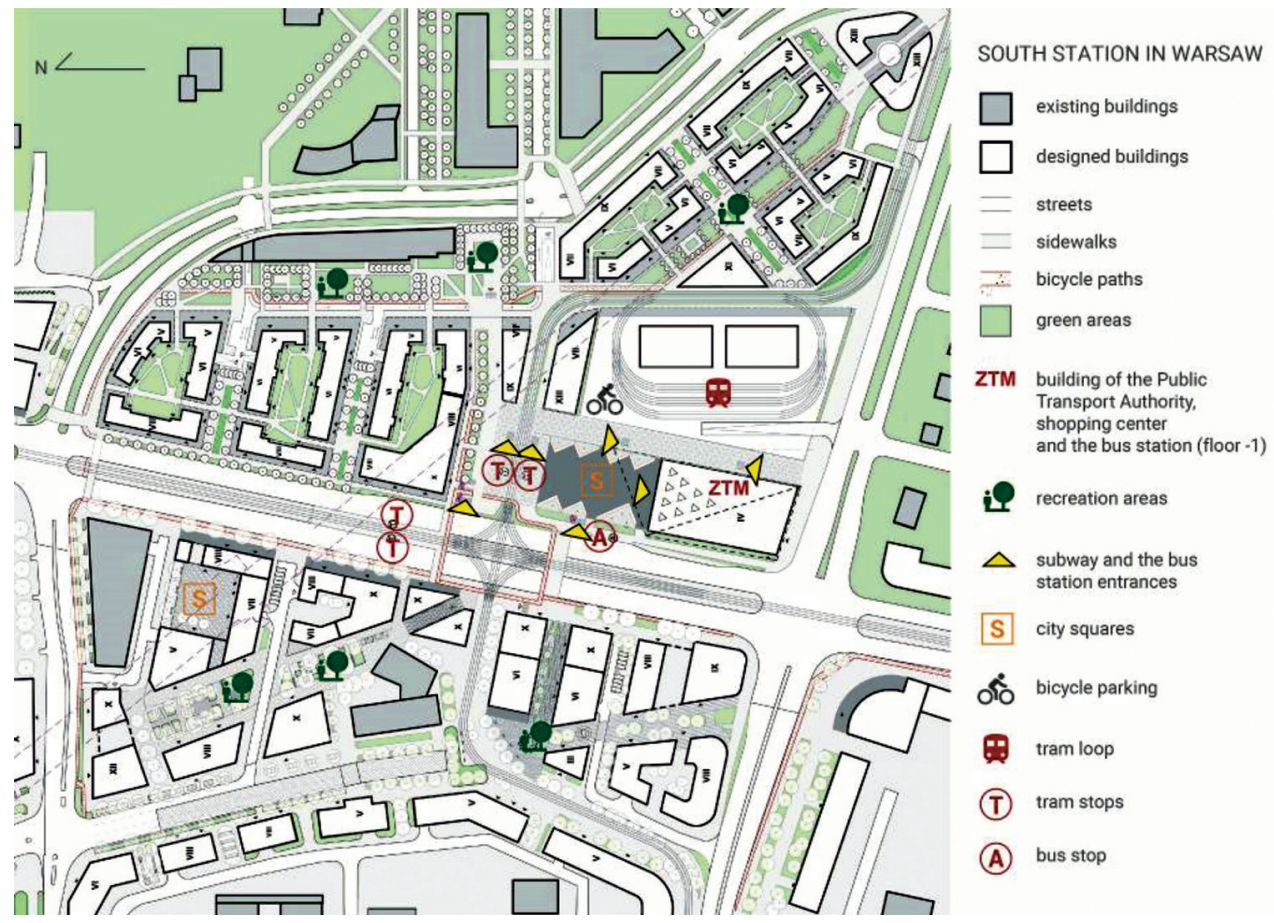

II. 4. Koncepcja zagospodarowania rejonu Dworca Południowego w Dzielnicy Mokotów m. st. Warszawy, Warszawa 2016, autorki: Agata Bosiacka, Urszula Mazanek, prowadzący projekt: dr hab. inż. arch. Katarzyna Pluta, prof. PW (źródło: Materiały archiwalne Katedry Projektowania Urbanistycznego i Krajobrazu Wiejskiego Wydziału Architektury Politechniki Warszawskiej) III. 4. Concept of development of "The South Station area in Mokotów District in Warsaw", Warsaw 2016 


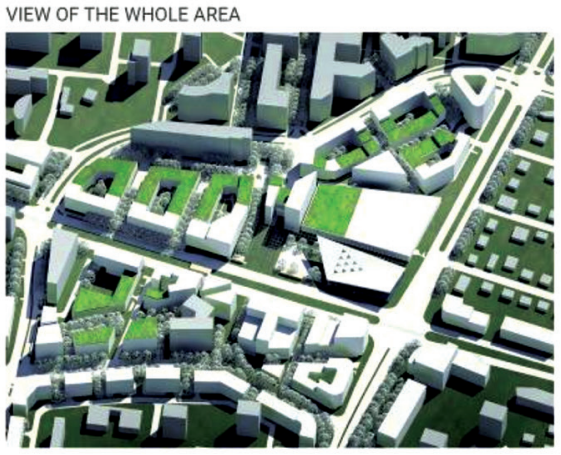

VIEW OF THE MAIN SQUARE
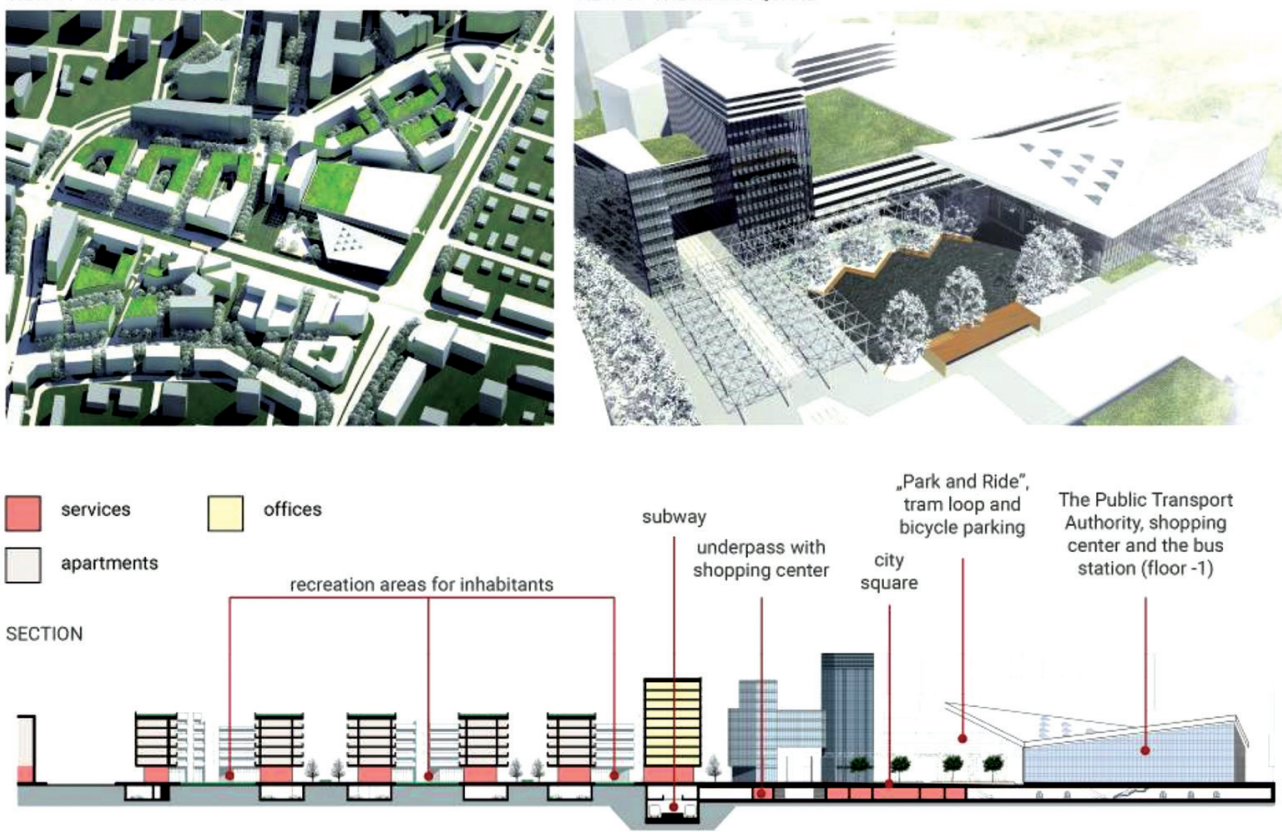

II. 5. Koncepcja zagospodarowania rejonu Dworca Południowego w Dzielnicy Mokotów m. st. Warszawy, Warszawa 2016, autorki: Agata Bosiacka, Urszula Mazanek, prowadzący projekt: dr hab. inż. arch. Katarzyna Pluta, prof. PW (źródło: Materiały archiwalne Katedry Projektowania Urbanistycznego i Krajobrazu Wiejskiego Wydziału Architektury Politechniki Warszawskiej) III. 5. Concept of development of "The South Station area in Mokotów District in Warsaw", Warsaw 2016 


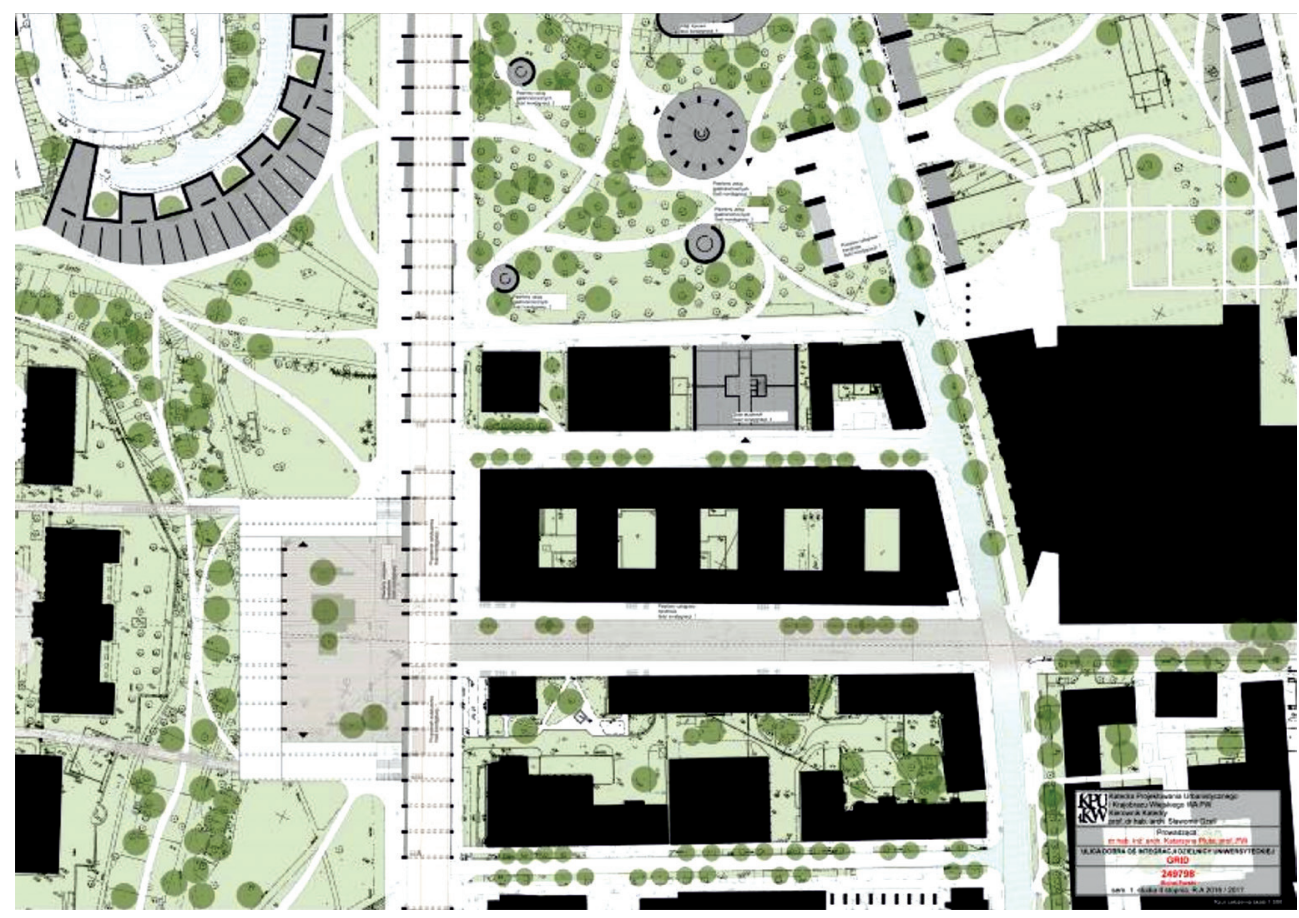

II. 6. Koncepcja pt. „Ulica Dobra jako oś integracji dzielnicy uniwersyteckiej”, Warszawa 2017, autor: Michał Purski, prowadzący projekt: dr hab. inż. arch. Katarzyna Pluta, prof. PW (źródło: Materiały archiwalne Katedry Projektowania Urbanistycznego i Krajobrazu Wiejskiego Wydziału Architektury Politechniki Warszawskiej)

III. 6. Concept of development: "Dobra Street as the axis of integration of the university district", Warsaw 2017 


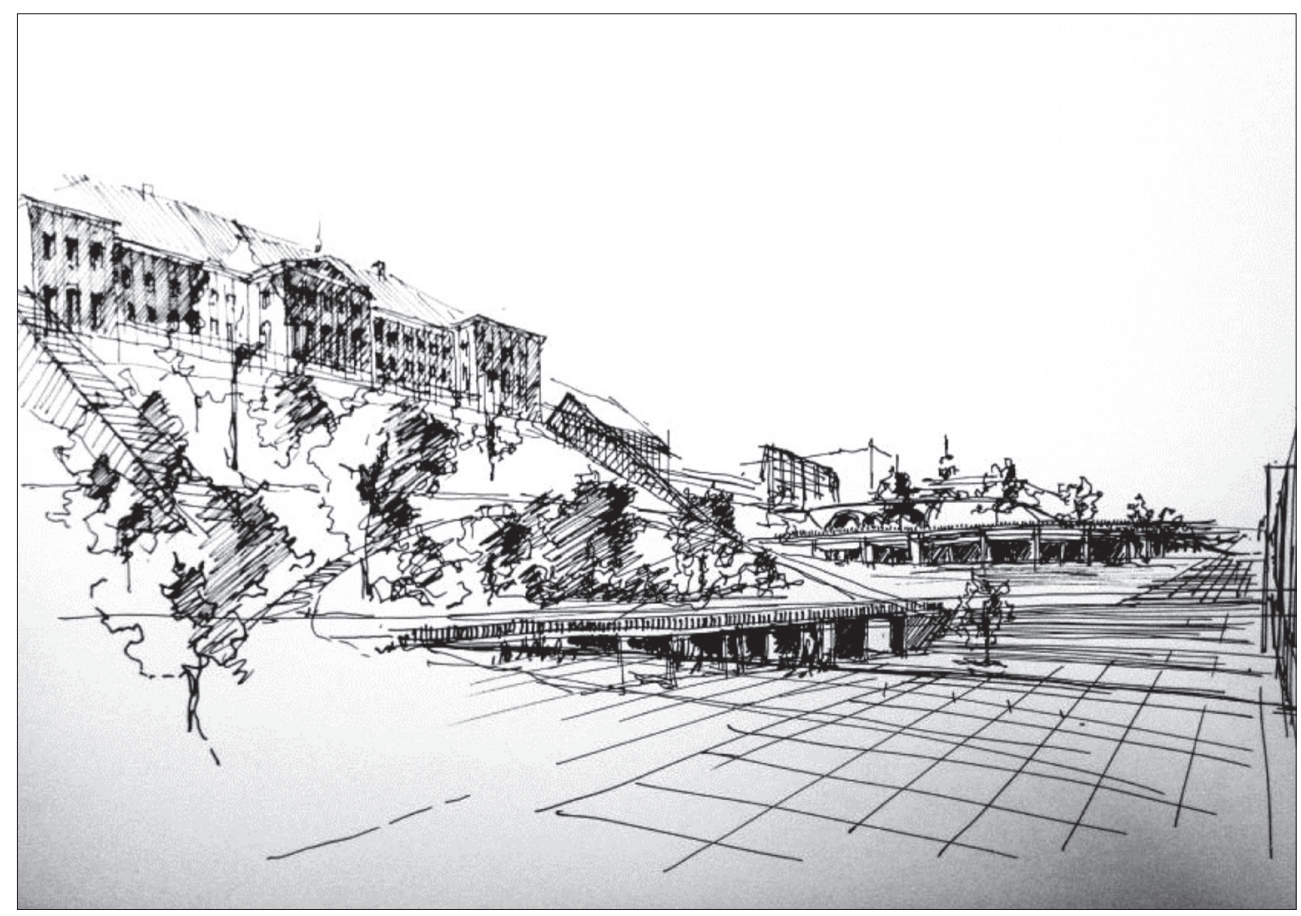

II. 7. Koncepcja pt. „Ulica Dobra jako oś integracji dzielnicy uniwersyteckiej”, Warszawa 2017, autor: Michał Purski, prowadzący projekt: dr hab. inż. arch. Katarzyna Pluta, prof. PW (źródło: Materiały archiwalne Katedry Projektowania Urbanistycznego i Krajobrazu Wiejskiego Wydziału Architektury Politechniki Warszawskiej)

III. 7. Concept of development: "Dobra Street as the axis of integration of the university district", Warsaw 2017 


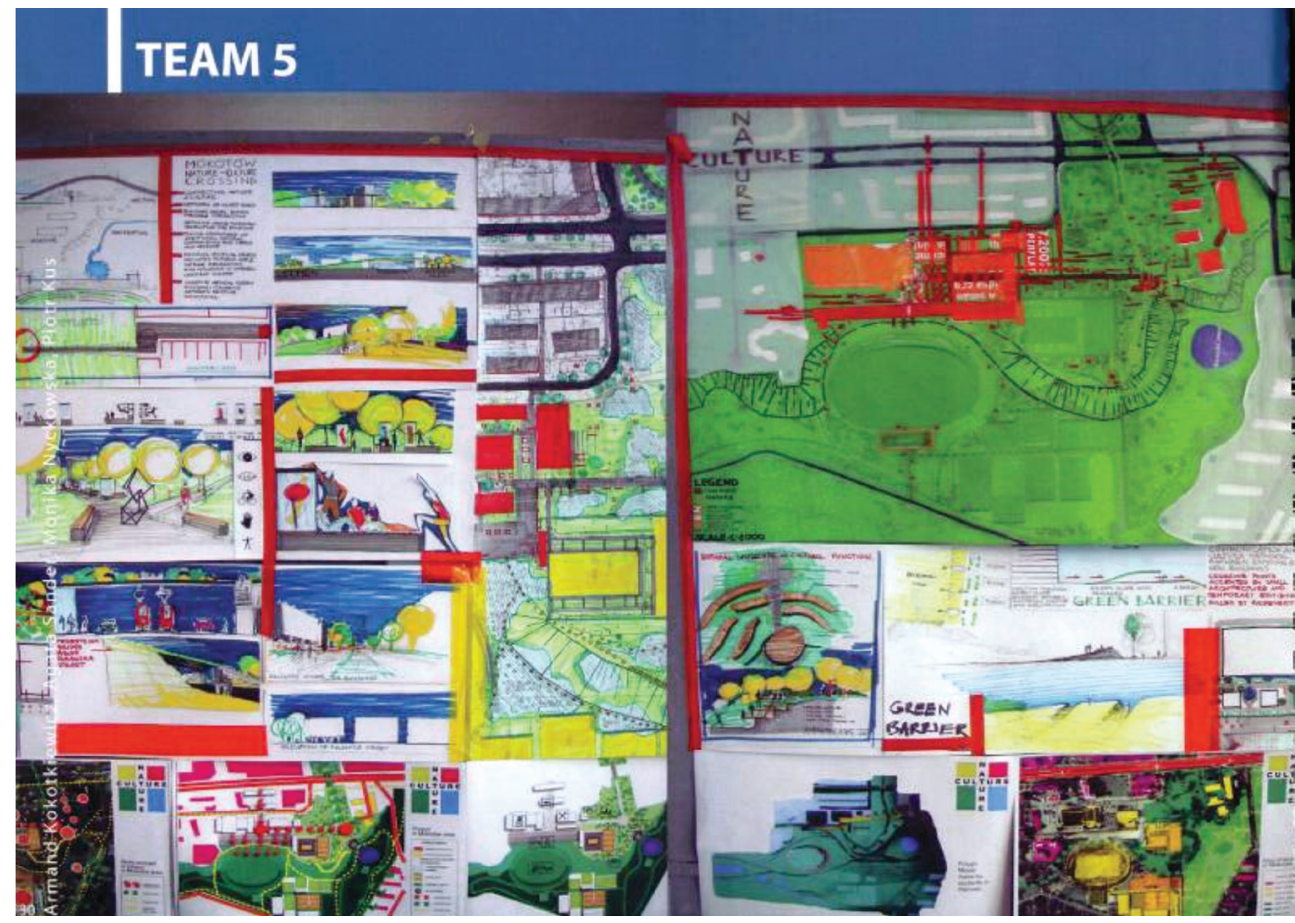

II. 8. „Seminarium fakultatywne Warszawa - Berlin”, pt. „Mokotów meeting point of Culture and Nature in Warsaw", Warszawa - Berlin 2007, autorzy: Armand Kokotkiewicz, Agata Sander, Monika Nyckowska, Piotr Kus (źródło: Materiały archiwalne Katedry Projektowania Urbanistycznego i Krajobrazu Wiejskiego Wydziału Architektury Politechniki Warszawskiej)

III. 8. Seminar Warsaw - Berlin, "Mokotów meeting point of Culture and Nature in Warsaw", Warsaw - Berlin 2007 


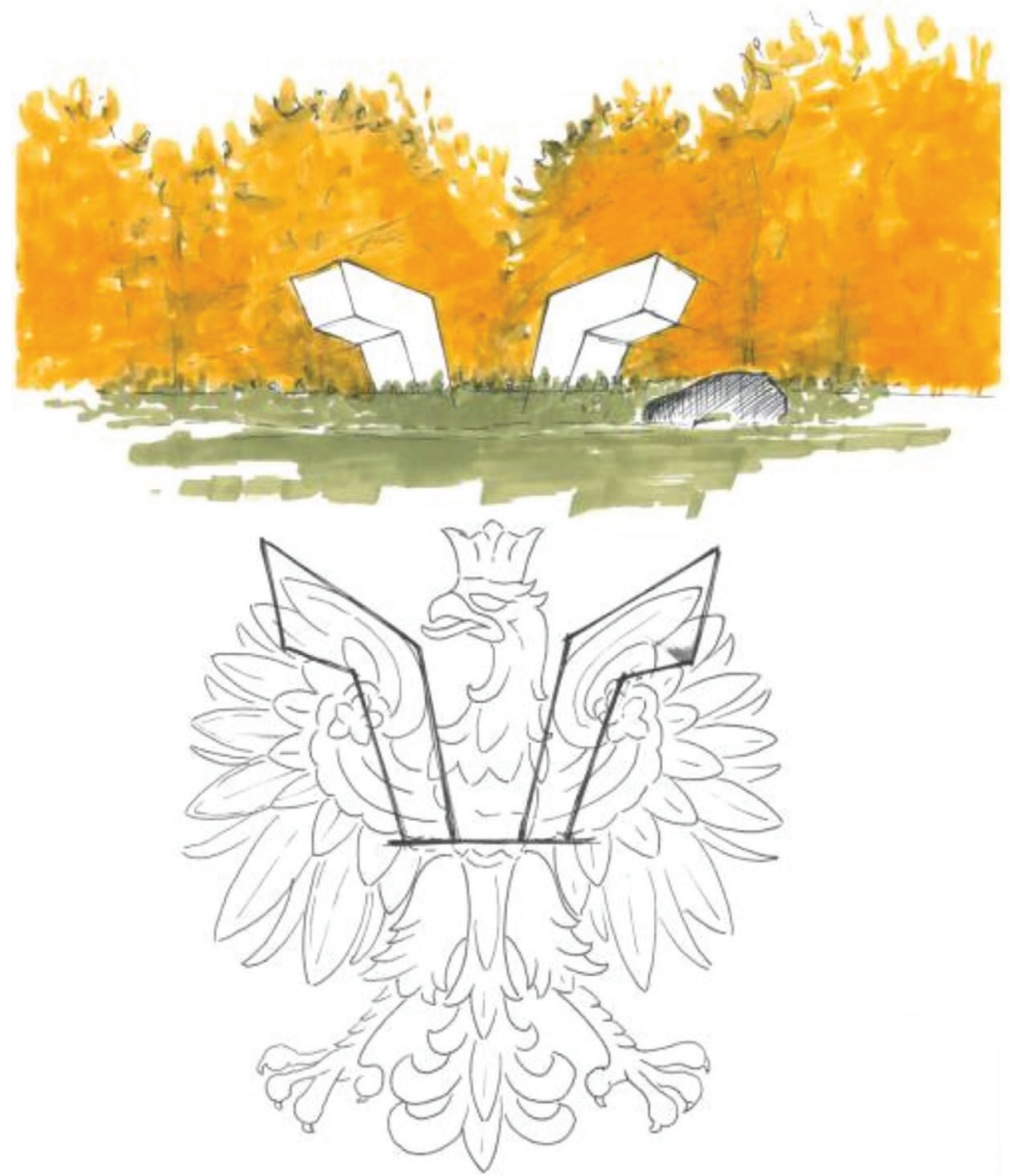

II. 9. Projekt pomnika Bitwy Warszawskiej 1920 roku, Warszawa 2015, autorka: Hanna Zbikowska (źródło: Materiały archiwalne Katedry Projektowania Urbanistycznego i Krajobrazu Wiejskiego Wydziału Architektury Politechniki Warszawskiej)

III. 9. Design of the Monument of the Battle of Warsaw 1920, Warsaw 2015 


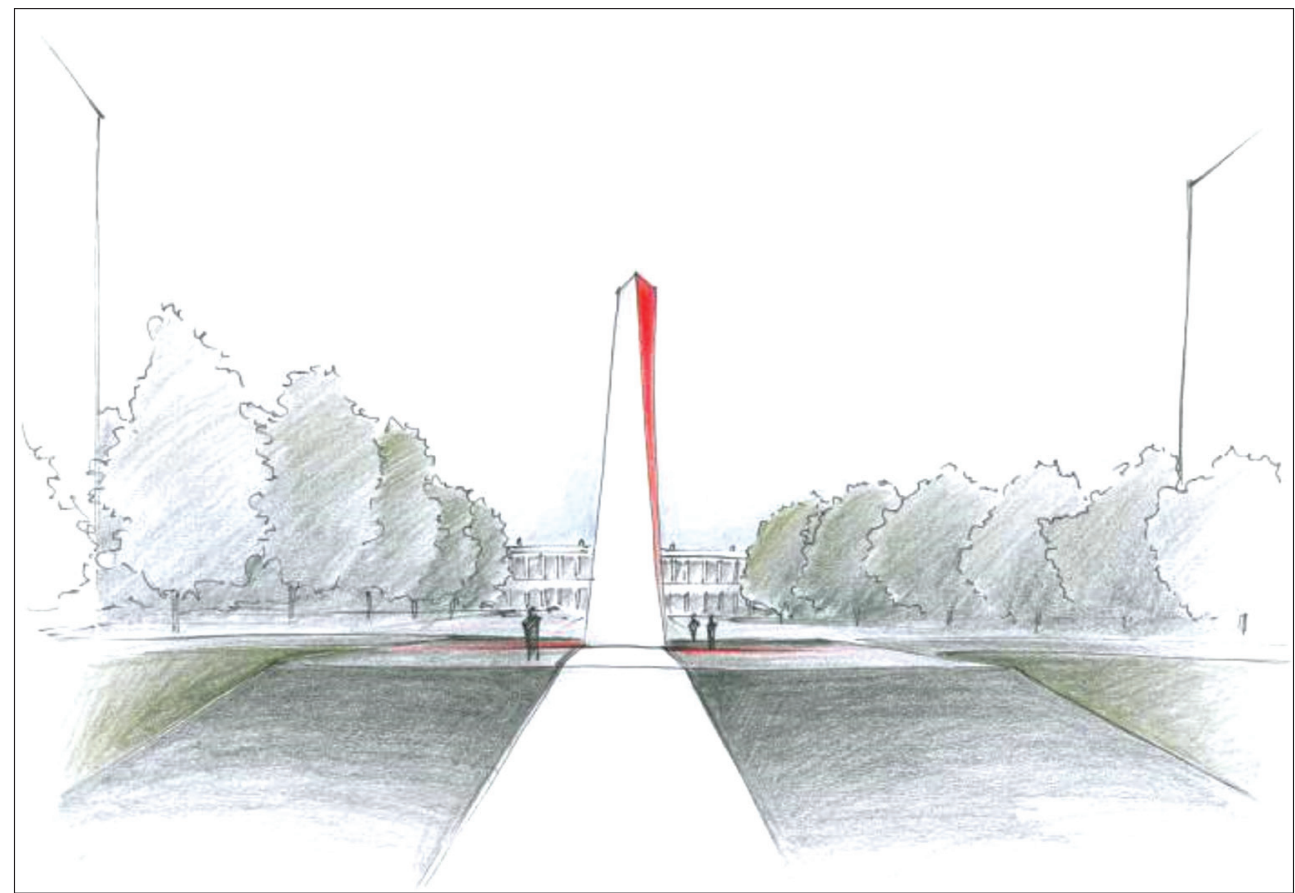

II. 10. Projekt pomnika Bitwy Warszawskiej 1920 roku, Warszawa 2015, autorka: Paulina Tomaszewska (źródło: Materiały archiwalne Katedry Projektowania Urbanistycznego i Krajobrazu Wiejskiego Wydziału Architektury Politechniki Warszawskiej)

III. 10. Design of the Monument of the Battle of Warsaw 1920, Warsaw 2015 


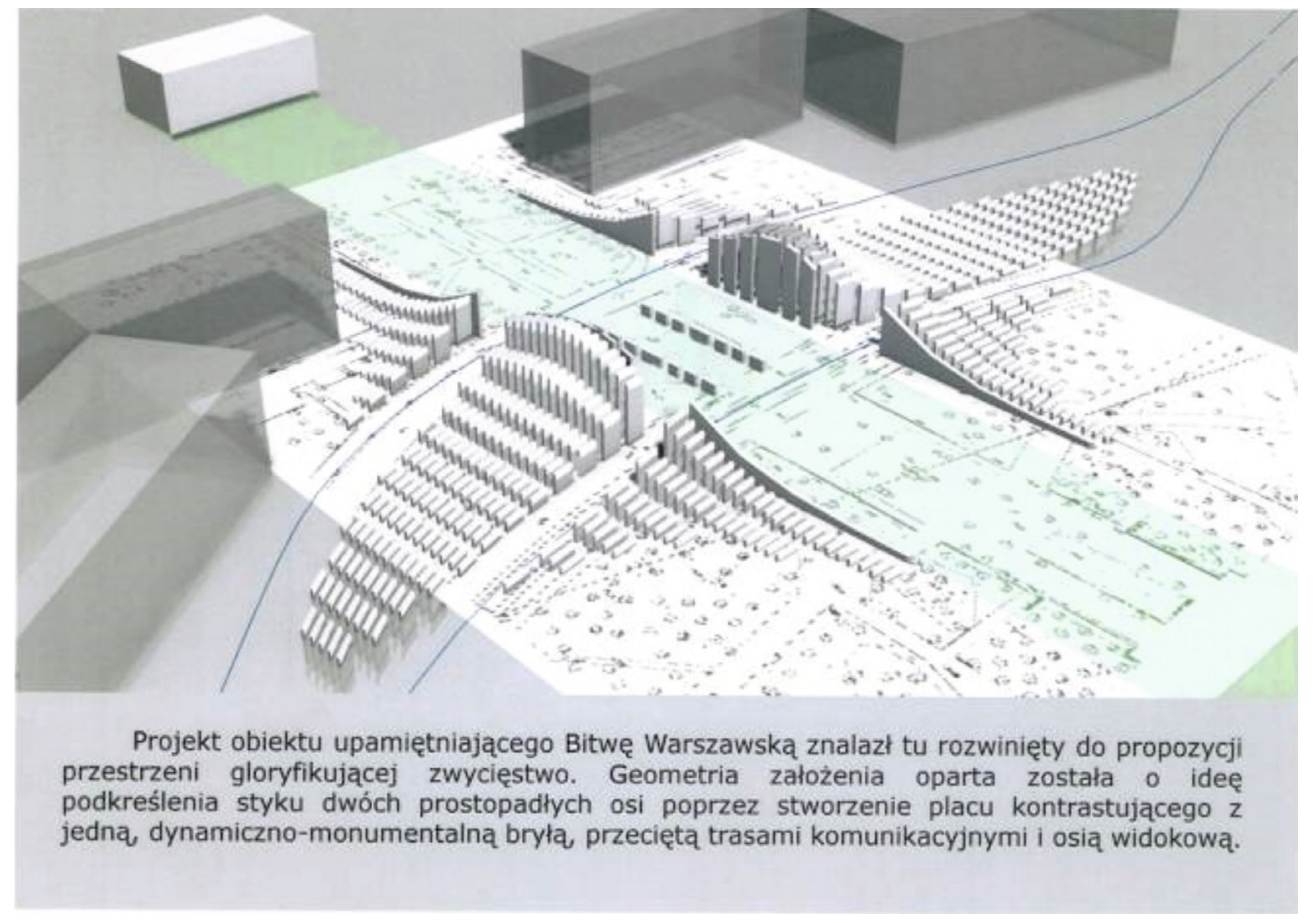

II. 11. Projekt pomnika Bitwy Warszawskiej 1920 roku, Warszawa 2015, autor: Łukasz Chaberka (źródło: Materiały archiwalne Katedry Projektowania Urbanistycznego i Krajobrazu Wiejskiego Wydziału Architektury Politechniki Warszawskiej)

III. 11. Design of the Monument of the Battle of Warsaw 1920, Warsaw 2015 


\section{PRZYPISY}

1 Materiały archiwalne Katedry Projektowania Urbanistycznego i Krajobrazu Wiejskiego Wydziału Architektury Politechniki Warszawskiej, Warszawa 2017.

2 K. Pluta, G. Podstata, N. Roskamm, S. Seelig, Urban Lock - nördliche Lohmühleninsel (Städtebaulicher Workshop zur Lohmühleninsel), Urban Design Workshop 2006, Fachgebiet Bestandsentwicklung und Erneuerung von Siedlungseinheiten, Institut für Stadt- und Regionalplanung, Technische Universität Berlin, Berlin 2006, s. 1-25.

3 S. Gzell, K. Pluta, N. Roskamm, Mokotów meeting point of Culture and Nature in Warsaw, Urban Design Workshop 2007, Institut für Stadt-und Regionalplanung, Technische Universität Berlin, Berlin 2007, s. 1-34.

4 Przesunięcie wschodniej jezdni ulicy Marszałkowskiej zostało skonkretyzowane w koncepcji rewaloryzacji Ogrodu Saskiego, powstałej w wyniku umowy zawartej w 1998 roku pomiędzy Gminą Warszawa - Centrum a Ośrodkiem Ochrony Zabytkowego Krajobrazu. Autorami koncepcji są architekci krajobrazu Wojciech Trzupek i Marek Szaniawski, przy współpracy Wojciecha Jarosińskiego, Ewy Kosiackiej i Agnieszki Matyszczyk, przy urbanistycznej konsultacji Grzegorza Chodkowskiego. Pracując nad jej koncepcją, autorzy przypomnieli zmienne losy Ogrodu Saskiego, w tym zmiany jego zachodniej granicy, co usprawiedliwiało np. nową lokalizację ulicy Marszałkowskiej.

5 Materiały archiwalne Katedry Projektowania Urbanistycznego i Krajobrazu Wiejskiego Wydziału Architektury Politechniki Warszawskiej, Warszawa 2015.

6 S. Gzell, Wstęp, [w:] Historyczny Kampus Szkoły Głównej Handlowej w Warszawie w studenckich konkursach urbanistycznych, Międzyuczelniane Zeszyty Naukowe, Wydział Architektury Politechniki Warszawskiej, Akapit-DTP, Warszawa 2014, s. 7.

\section{BIBLIOGRAFIA}

Gzell S., Pluta K., Roskamm N., Mokotów meeting point of Culture and Nature in Warsaw, Urban Design Workshop 2007, Institut für Stadt-und Regionalplanung, Technische Universität Berlin, Berlin 2007, s. 1-34.

Historyczny Kampus Szkoły Głównej Handlowej w Warszawie w studenckich konkursach urbanistycznych, Międzyuczelniane Zeszyty Naukowe, Wydział Architektury Politechniki Warszawskiej, Akapit-DTP, Warszawa 2014.

Materiały archiwalne Katedry Projektowania Urbanistycznego i Krajobrazu Wiejskiego Wydziału Architektury Politechniki Warszawskiej, Warszawa 2017.

Materiały archiwalne Katedry Projektowania Urbanistycznego i Krajobrazu Wiejskiego Wydziału Architektury Politechniki Warszawskiej, Warszawa 2015.

Pluta K., Podstata G., Roskamm N., Seelig S., Urban Lock - nördliche Lohmühleninsel (Städtebaulicher Workshop zur Lohmühleninsel), Urban Design Workshop 2006, Fachgebiet Bestandsentwicklung und Erneuerung von Siedlungseinheiten, Institut für Stadt- und Regionalplanung, Technische Universität Berlin, Berlin 2006, s. 1-25. 